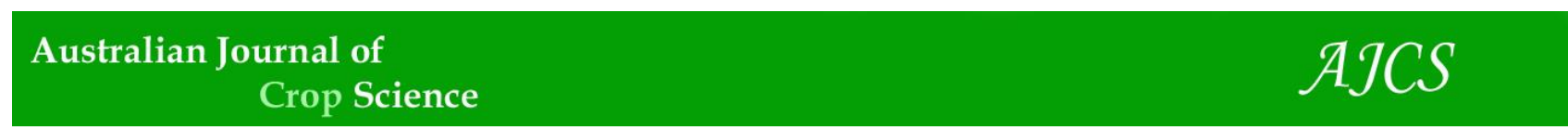

AJCS 13(03):367-371 (2019)

ISSN:1835-2707

doi: 10.21475/ajcs.19.13.03.p1188

\title{
Control strategies for Chrysodeixis includens and Spodoptera eridania caterpillars (Lepidoptera: Noctuidae) and selection of resistant cultivars in soybean
}

\author{
Paulo Vinicius de Sousa ${ }^{1}$, Adriana Gonçalves Vaz ${ }^{1}$, Debora Souza Miranda ${ }^{1}$, Patricia Vaz da Costa ${ }^{1}$, Andre \\ Cirilo Sousa Almeida ${ }^{1}$, Marcio Silva Araújo ${ }^{2}$, Flávio Gonçalves de Jesus* ${ }^{1}$
}

\author{
${ }^{1}$ Instituto Federal Goiano, Campus Urutaí, Rodovia Prof. Geraldo Silva Nascimento, 75790-000, Urutaí, Goiás, Brazil \\ ${ }^{2}$ Universidade Estadual de Goiás (UEG), GO 330, Km 241, Anel Viário, s/n, 75780-000, Ipameri, Goiás, Brazil
}

*Corresponding author: flavio.jesus@ifgoiano.edu.br

\begin{abstract}
Chrysodeixis includens and Spodoptera eridania caterpillars have been considered the most important pests for Glycine max in Brazil. This study evaluated different control strategies for these two important soybean caterpillars and the effects on crop productivity. The control strategies adopted were: BC, IPM, PUI and C (without pest control) and 2 cultivars (BMX Desafio conventional and TEC Power IPRO - transgenic - Cry 1Ac). The experimental design was in randomized blocks in a factorial scheme $(2 \times 4)$ with four replications. The transgenic cultivar TEC Power IPRO presents efficiency in the control of Chrysodeixis includens and low efficiency for Spodoptera eridania. Harmonious practices such as IPM are the best alternative for soybean crops, to minimize Chrysodeixis includens and Spodoptera eridania infestations. The control strategy adopted did not influence soybean productivity.
\end{abstract}

Keywords: Integrated pest management, rational insecticide use, transgenic soybean, plant resistance to insects.

Abbreviations: BC_biological control; IPM_integrated pest management; PUI_prophylactic insecticides use; C_control, PRI_plant resistance to insect; IGRs_insect-growth regulators; DAPE_days after plant emergence; PCLA_percentage of cut leaf area; ANOVA_analysis of variance.

\section{Introduction}

The soybean Glycine max (L.) Merril is one of the most cultivated crops in the world, being used for human and animal food and as a source of renewable energy. However, this crop is damaged by insect pests that cause reduced crop productivity and grain quality (Hoffmann-Campo et al., 2012).

Among the main pests of the soybean are the Lepidoptera: Chrysodeixis (Pseudoplusia) includens (Walker), Anticarsia gemmatalis (Hübner) (Lepidoptera: Noctuidae), the caterpillars of the genus Spodoptera spp. and soybean stink bugs Euschistus heros (Fabricius), Piezodorus guildinii (Westwood.) and Nezara viridula (Linnaeus) (Hemiptera: Pentatomidae) which are associated with damage, reduced grain quality and physiological disorders in soybean plants (Chocorosqui and Panizzi, 2004; Temple et al., 2013; Marques et al., 2016).

The main pest control method adopted in soybean cultivation is chemical control using insecticide spraying, which can cause environmental and human health problems as well as select for resistant insect pest populations (Carmo et al., 2010; Martins and Tomquelski, 2015).

In integrated pest management programs (IPM), control strategies need to be employed and the interaction of PRI (conventional or transgenic) needs to be compatible with all control methods (Boiça Junior et al., 2015; Souza et al., 2016). RPI was shown to be efficient, reducing pest populations below the level of economic damage consequently reducing production costs and insecticide use (Smith, 2005; Seifi et al., 2013). However, little is known about the interaction between RPI, insecticide use and biological control in pest control in soybean crops (Zalucki et al., 2009; Bueno et al., 2011).

The development of conventional soybean cultivars resistant to insects, such as IAC-17, IAC-18 and IAC-100, provided greater pest control efficiency (Miranda et al., 2003). However, with the introduction of transgenic soybean plants in 2013, expressing $\delta$-endotoxins (Cry 1 Ac proteins) from the bacterium Bacillus thuringiensis Berliner $(\mathrm{B} t)$ in Brazil, new research options for management strategies are necessary as a tool in soybean IPM (Souza et al., 2014a; Souza et al., 2014; Souza et al., 2016). This technology efficiently controls velvet bean caterpillar (Anticarsia gemmatalis - Hübner), soybean looper (Chrysodeixis includens - Walker and Rachiplusia nu Guenée), soybean budborer (Crocidosema aporema Walsingham), tobacco budworm (Heliothis virescens Fabrícius), lesser cornstalk borer (Elasmopalpus lignosellus Zeller), corn earworm (Helicoverpa zea - Boddie) and old world bollworm (Helicoverpa armigera - Hübner) (Marques et al., 2016).

The evaluation of different pest control strategies is interesting, assisting soybean growers to choose efficient methods in harmony with the environment (Bueno et al., 2010). Bueno et al., 2011 observed different levels of pest infestation depending on the control strategy adopted. In biological control and IPM - insecticide, a higher pest 
incidence was observed, however crop productivity remained the same when prophylactic insecticide applications were adopted. It was concluded that excessive insecticide use does not generate an increase in soybean productivity and that IPM practices are the best alternative for pest control.

This study aimed to evaluate different management strategies for Chrysodeixis includens and Spodoptera eridania caterpillars (Lepidoptera: Noctuidae) in soybean crops.

\section{Results}

The caterpillar infestation presented a statistical difference between the cultivars at 30 DAPE. The soybean looper Chrysodeixis includens (Lepidoptera: Noctuidae) occurred in higher numbers in $\mathrm{BMX}$ Desafio (conventional) $(\mathrm{F}=35.92 ; \mathrm{P}=$ $<0.0005)$ than in TEC Power IPRO (F=6.92; $P=0.0201)$. The control strategies did not differ statistically in this period for C. includens $(F=0.56 ; P=0.6447)$. Spodoptera eridania (Lepidoptera: Noctuidae) showed the highest infestation in TEC Power IPRO (F=6.32; $P=0.0201)$ in the IPM strategy, without statistical difference from the $\mathrm{BC}$ and $\mathrm{C}(\mathrm{F}=2.95 ; P=$ 0.0561) (Table 1).

C. includens infestations at 45 DAPE were higher in $\mathrm{BMX}$ Desafio ( $F=63.48 ; P \leq 0.005)$ and the control strategies did not differ at this stage $(F=1.32 ; P=0.290)$. The cultivars and control strategies did not differ statistically for $S$. eridania infestation at 45 DAPE ( $F=0.63 ; P=0.430)$. Defoliation was higher in the cultivar BMX Desafio $(F=63.87 ; P \leq 0.005)$, and PUI $(F=5.35 ; P=0.0067)$ provided the highest percentage of defoliation (Table 1).

At 60 DAPE, the highest $C$. includens infestation was in BMX Desafio $(F=81.55 ; P \leq 0.0005)$ and the control strategies did not differ $(F=1.18 ; P=0.3338)$. The cultivars did not differ for $S$. eridania $(F=2.68 ; P=0.1160)$, and the greatest caterpillar infestation was in $\mathrm{BC}$, however it did not differ from $\mathrm{PUI}$ and $\mathrm{C}(\mathrm{F}=2.52 ; P=0.0856)$. The percentage of defoliation was higher in $\mathrm{BMX}$ Desafio $(\mathrm{F}=56.16 ; P \leq 0.0005)$ and the control strategies did not influence this parameter ( $F$ $=1.31 ; P=0.2961)$ (Table 1).

At 75 DAPE, the $C$. includens infestation was highest in $B M X$ Desafio $(\mathrm{F}=81.75 ; P \leq 0.0005)$. The $\mathrm{PUI}$ control strategy $(\mathrm{F}=$ 3.79, $P=0.0255$ ) led to the greatest $C$. includens infestation. Cultivars and control strategies did not influence $S$. eridania infestation at 75 DAPE. The highest percentage of defoliation was observed in BMX Desafio $(F=63.82 ; P \leq 0.0005)$ in the $\mathrm{BC}$ and $\mathrm{PUI}(\mathrm{F}=8.63 ; P=0.0063$ ) (Table 1$)$.

The interaction of cultivars versus control strategies at 45 DAPE for the percentage of defoliation, showed the highest value in BMX Desafio in C. The control strategies did not influence the percentage of defoliation in TEC Power IPRO. The number of $C$. includens at 75 DAPE was highest in BMX Desafio, while TEC Power IPRO presented no $C$. includens infestations regardless of the control strategy adopted. For the percentage of defoliation at $75 \mathrm{DAPE}$, the highest values were in BMX Desafio in C and IPM. The control strategies did not influence the percentage of defoliation during this period (Table 2).

The highest productivity was in BMX Desafio compared to TEC Power IPRO ( $F=18.50 ; P=0.0053$ ) while the control strategies $(F=1.99 ; P=0.1463)$ did not influence soybean crop yields (Figure 1 ).

\section{Discussion}

In the evaluation of 30 DAPE, low infestation by the two caterpillar species was observed, with a greater number in BMX Desafio (conventional), however without defoliation. The presence of $C$. includens was observed in the TEC Power IPRO (transgenic) cultivar. These caterpillars were neonates that died from feeding on the soybean plant and ingesting $B t$ protein (Cry 1 Ac) (Bernardi et al., 2014). This protein associates with receptors in the microvilli of the intestine of the insects, causing osmotic lysis and consequently caterpillar death (Bobrowski et al., 2003).

The fact that $S$. eridania fed on the transgenic TEC Power IPRO cultivar shows that the Cry 1 Ac protein is not effective in the control of this caterpillar. Spodoptera cosmioides (Lepidoptera: Noctuidae) had completed the biological cycle in transgenic soybean cultivars (Boiça Junior et al., 2015). This protein presents low toxicity to $S$. cosmiodis, S. eridania and Spodptera frugiperda (Lepidoptera: Noctuidae), being a strategy inadequate to reduce the population of these caterpillars in the soybean crop (Santos et al., 2009; Bernardi et al., 2014). The control of some species of the genus Spodoptera in Bt soybean is not yet clear, such as S. eridania (Liu et al., 2005; Naranjo, 2005; Faria et al., 2007; Whitehouse et al., 2007); however, in some regions of Brazil, this species has been a key pest in soybean crops (Bueno et al., 2011; Bernardi et al., 2014).

In the evaluations at 45, 60 and 75 DAPE, the effectiveness of Bt protein (Cry $1 \mathrm{Ac}$ ) present in TEC Power IPRO was verified in the control of $C$. includens, where infestation of plants by this caterpillar was not observed. This shows the importance of $B t$ soybean in the IPM of leafhopper caterpillars, reducing the damage caused by these insects and reducing the use of chemical pesticides (Bobrowski et al., 2003).

The presence of $S$. eridania was observed in all evaluations of soybean crops. Other studies have shown the low efficiency in the control of caterpillars of the genus Spodoptera with adoption of Bt soybean (Santos et al., 2009; Bernardi et al., 2014). S. frugiperda completed its biological cycle feeding on Bt soybean, however, it presented a prolonged larval phase, reduced larval viability, increased average generation time and reduced intrinsic growth rate (Bernardi et al., 2014). The low efficiency of Cry $1 \mathrm{Ac}$ in the control of caterpillars of the genus Spodoptera is possibly related to the tolerance of this group to different types of $\mathrm{B} t$ protein, the genetic variability between the populations of the pest and/or the inactivation of the insecticidal protein by proteases produced by these caterpillars (Miranda et al., 2001; Rahman et al., 2012).

Bt soybean shows low efficiency in the control of species of the genus Spodoptera, and other control tactics should be implemented under field conditions. This was exemplified in the observations of the control strategies throughout the evaluations. At $30 \mathrm{DAPE}$, the lowest $S$. eridania infestation was observed in the $B C$ and $C$, without differing from the PUI. At 45 DAPE, the lowest $S$. cosmioides infestation was in the TEC Power IPRO cultivar in the CB and IPM, without differing from C. At $60 \mathrm{DAPE}$, no S. eridania infestation was observed in the IPM.

In general, throughout the evaluations, the lowest $S$. eridania infestations were observed in TEC Power IPRO (Cry 1Ac) using the $B C$ and IPM strategies. This demonstrates the importance of adopting harmonious practices such as $B C$ and IPM in soybean cultivation systems. Bueno et al. (2011) 
Table 1. Number of Chrysodeixis includens (Lepidoptera: Noctuidae) and Spodoptera eridania (Lepidoptera: Noctuidae) in one linear meter at 30, 45, 60 and 75 DAPE in different control strategies. Cristalina, Goiás, Brazil. 2016/2017.

\begin{tabular}{|c|c|c|c|c|c|c|}
\hline \multirow[b]{2}{*}{ Cultivars $(A)^{1}$} & \multicolumn{2}{|c|}{30 DAPE } & \multicolumn{4}{|c|}{$45 \mathrm{DAPE}$} \\
\hline & C. $\mathrm{i}$ & S.e & C.i & & S.e & Def. \\
\hline BMX Desafio & $2.62 \mathrm{a}$ & $0.25 b$ & $2.87 \mathrm{a}$ & & $0.12 a$ & $5.62 \mathrm{a}$ \\
\hline TEC Power IPRO & $0.25 b$ & $0.87 \mathrm{a}$ & $0.00 \mathrm{~b}$ & & $0.25 a$ & $0.62 b$ \\
\hline$F(A)$ & $35.92^{*}$ & $6.32^{*}$ & $63.48^{*}$ & & $0.63^{\text {ns }}$ & $63.87^{*}$ \\
\hline$P$ value $(A)$ & $<0.0005$ & 0.0020 & $<0.000$ & & 0.4300 & $<0.0005$ \\
\hline \multicolumn{7}{|l|}{ Treatments (B) } \\
\hline $1-B C$ & $1.00 \mathrm{a}$ & $0.37 \mathrm{ab}$ & $1.50 \mathrm{a}$ & & $0.25 a$ & $2.06 \mathrm{~b}$ \\
\hline $2-I P M$ & $1.62 \mathrm{a}$ & $1.12 \mathrm{a}$ & $1.12 \mathrm{a}$ & & $0.00 \mathrm{a}$ & $2.12 b$ \\
\hline 3 - PUI & $1.50 \mathrm{a}$ & $0.62 a b$ & $2.00 \mathrm{a}$ & & $0.13 a$ & $5.12 \mathrm{a}$ \\
\hline $4-C$ & $1.62 \mathrm{a}$ & $0.12 b$ & $1.12 \mathrm{a}$ & & $0.37 a$ & $3.25 \mathrm{ab}$ \\
\hline$F(B)$ & $0.56^{\mathrm{ns}}$ & $2.95^{*}$ & $1.32^{\mathrm{ns}}$ & & $1.06^{\text {ns }}$ & $5.35^{* *}$ \\
\hline$P$ value (B) & 0.6447 & 0.0561 & 0.2900 & & 0.3800 & 0.0067 \\
\hline$F(A \times B)$ & $0.96^{\mathrm{ns}}$ & $0.92^{\text {ns }}$ & $1.32^{\mathrm{ns}}$ & & $2.75^{\text {ns }}$ & $4.92^{* *}$ \\
\hline$P$ value $(A \times B)$ & 0.420 & 0.445 & 0.290 & & 0.060 & 0.009 \\
\hline \multirow[b]{2}{*}{ Cultivars (A) } & \multicolumn{3}{|c|}{60 DAPE } & \multicolumn{3}{|c|}{75 DAPE } \\
\hline & C. $\mathrm{i}$ & S.e & Def. & C. $\mathrm{i}$ & S.e & Def. \\
\hline BMX Desafio & $5.00 \mathrm{a}$ & 0.68 & $5.68 a$ & $6.68 a$ & $0.62 \mathrm{a}$ & $7.56 a$ \\
\hline TEC Power IPRO & $0.00 \mathrm{~b}$ & 0.18 & $1.31 \mathrm{~b}$ & $0.00 \mathrm{~b}$ & $0.12 \mathrm{a}$ & $1.43 \mathrm{~b}$ \\
\hline$F(A)$ & $81.55^{*}$ & $2.68^{\text {ns }}$ & $56.16^{*}$ & $81.75^{* *}$ & $2.75^{\text {ns }}$ & 63.82 \\
\hline$P$ value $(A)$ & $<0.0005$ & 0.116 & $<0.005$ & $<0.0055$ & 0.1118 & $<0.005$ \\
\hline \multicolumn{7}{|l|}{ Treatments (B) } \\
\hline $1-B C$ & $3.00 \mathrm{a}$ & $1.12 \mathrm{a}$ & $3.87 \mathrm{a}$ & $2.50 \mathrm{~b}$ & $0.12 \mathrm{a}$ & $2.87 \mathrm{~b}$ \\
\hline $2-I P M$ & $2.62 \mathrm{a}$ & $0.00 \mathrm{~b}$ & $3.87 \mathrm{a}$ & $2.75 a b$ & $1.00 \mathrm{a}$ & $6.37 \mathrm{a}$ \\
\hline 3 - PUI & $2.75 \mathrm{a}$ & $0.37 a b$ & $2.50 \mathrm{a}$ & $5.50 \mathrm{a}$ & $0.00 \mathrm{a}$ & $2.25 \mathrm{~b}$ \\
\hline $4-C$ & $1.62 \mathrm{a}$ & $0.25 a b$ & $3.75 \mathrm{a}$ & $2.62 \mathrm{ab}$ & $0.37 \mathrm{a}$ & $6.50 a$ \\
\hline$F(B)$ & $1.18^{\mathrm{ns}}$ & $2.52^{\mathrm{ns}}$ & $1.31^{\mathrm{ns}}$ & $3.79^{*}$ & $2.18^{\mathrm{ns}}$ & $8.63^{* *}$ \\
\hline$P$ value $(B)$ & 0.3336 & 0.0856 & 0.2961 & 0.0255 & 0.1204 & 0.006 \\
\hline$F(A \times B)$ & $1.18^{\text {ns }}$ & $1.00^{\text {ns }}$ & $0.13^{\mathrm{ns}}$ & $3.79^{* *}$ & $1.26^{\mathrm{ns}}$ & $4.19^{* *}$ \\
\hline$P$ value $(A \times B)$ & 0.334 & 0.409 & 0.9364 & 0.025 & 0.312 & 0.0179 \\
\hline
\end{tabular}

${ }^{1}$ Means followed by the same letter do not differ significantly according to the Tukey test at $5 \%$ probability. C. $\mathrm{i}=$ Chrysodeixis includes; S.e $=$ Spodoptera eridania; Def $=$ Percentage of defoliation.

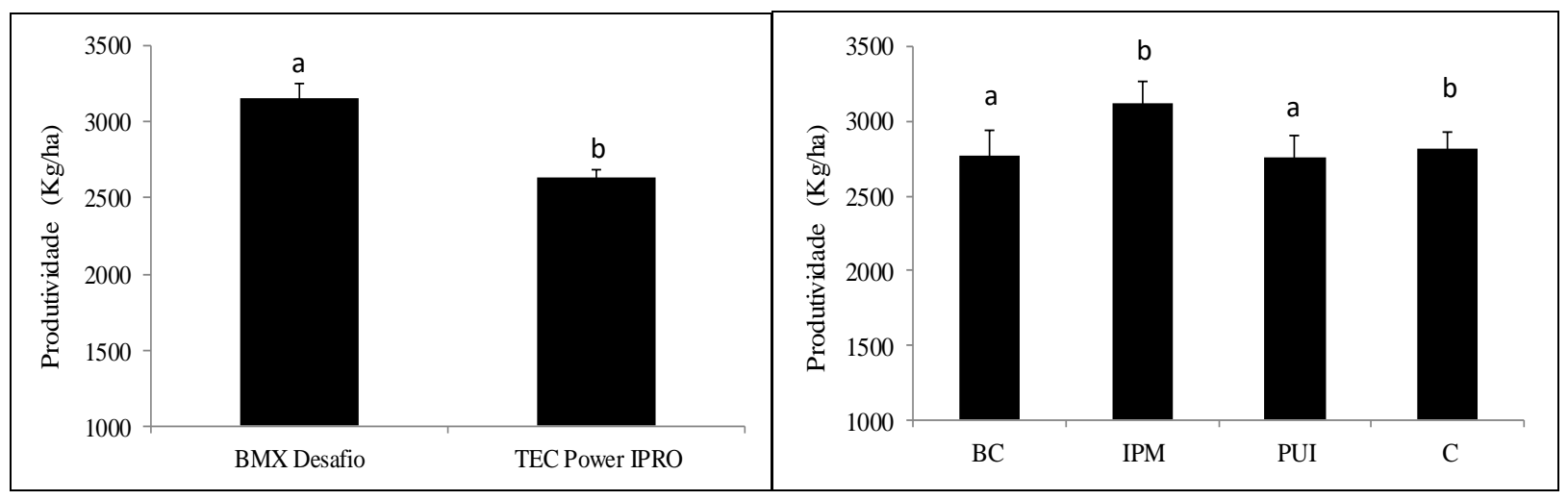

A

B

Fig 1. Productivity (kg/ha) in two soybean cultivars (A) using different control strategies (B) infested by Chrysodeixis includens and Spodoptera eridania (Lepidoptera: Noctuidae). The different letters on the bars represent averages statistically separated by the Tukey test $(p<0.05)$. F treatments $(A)=18.50^{* *}$ and $P$ Value $(A)=0.0053 ; F$ treatments $(b)=1.99$ and $P$ Value $(b)=0.1463$. $B C=$ Biological control; IPM = Integrated pest management; $\mathrm{PUI}=$ prophylactic insecticide use and $\mathrm{C}=$ Control. Cristalina. Goiás. Brazil. 2016/2017. 
Table 2. Use of soybean cultivars and control strategies at 45 DAE for the percentage of defoliation and the number of Crysodeixis includens per linear meter and percentage of defoliation at 75 DAE. Cristalina. Goiás. Brazil. 2016/2017.

\begin{tabular}{|c|c|c|c|c|c|c|}
\hline \multirow{2}{*}{ Cultivars $(A)^{1}$} & \multicolumn{4}{|c|}{ Treatments (T) at 45 DAPE - \% Def. } & \multirow{2}{*}{$F(V)$} & \multirow[t]{2}{*}{$P$ value $(V)$} \\
\hline & $B C$ & IPM & PIU & C & & \\
\hline BMX Desafio & $4.00 \mathrm{aB}$ & $6.25 \mathrm{aAB}$ & $4.00 \mathrm{aB}$ & $9.25 \mathrm{aA}$ & $8.62^{*}$ & $<0.0005$ \\
\hline TEC Power IPRO & $0.00 \mathrm{bA}$ & $0.25 \mathrm{bA}$ & $1.00 \mathrm{bA}$ & $1.25 \mathrm{bA}$ & $0.49^{\mathrm{ns}}$ & 0.7183 \\
\hline$F(T)$ & $11.15^{*}$ & $25.09^{*}$ & $6.27^{\mathrm{ns}}$ & $128^{* *}$ & & \\
\hline$P$ value $(T)$ & 0.0043 & $<0.0005$ & $<0.0005$ & 0.1765 & & \\
\hline \multirow{2}{*}{ Cultivars (A) } & \multicolumn{4}{|c|}{ Treatments (T) at 75 DAPE - $\mathrm{N}^{\circ} \mathrm{C} . \mathrm{i}$} & \multirow{2}{*}{$F(V)$} & \multirow[t]{2}{*}{$P$ value $(\mathrm{V})$} \\
\hline & $B C$ & IPM & PIU & C & & \\
\hline BMX Desafio & $5.00 \mathrm{aB}$ & $5.5 \mathrm{aB}$ & $5.25 \mathrm{aB}$ & $11.0 \mathrm{aA}$ & $7.59^{*}$ & 0.0013 \\
\hline TEC Power IPRO & $0.00 \mathrm{bA}$ & $0.00 \mathrm{bA}$ & $0.00 \mathrm{bA}$ & $0.00 \mathrm{bA}$ & $0.00^{\mathrm{ns}}$ & 1.0 \\
\hline$F(T)$ & $11.42^{*}$ & $13.82^{*}$ & $12.59^{*}$ & $55.29^{*}$ & & \\
\hline$P$ value $(T)$ & 0.0028 & 0.0013 & $<0.0005$ & 0.0019 & & \\
\hline \multirow{2}{*}{ Cultivars (A) } & \multicolumn{4}{|c|}{ Treatments ( $T$ ) at 75 DAPE - \% Def. } & \multirow{2}{*}{$F(V)$} & \multirow[t]{2}{*}{$P$ value $(\mathrm{V})$} \\
\hline & $B C$ & IPM & PIU & C & & \\
\hline BMX Desafio & $5.00 \mathrm{aB}$ & $10.00 \mathrm{aA}$ & $3.75 \mathrm{aB}$ & $11.50 \mathrm{aA}$ & $12.06^{* *}$ & $<0.0005$ \\
\hline TEC Power IPRO & $0.75 \mathrm{bA}$ & $2.75 \mathrm{bA}$ & $0.75 \mathrm{aA}$ & $1.50 \mathrm{bA}$ & $0.75^{\mathrm{ns}}$ & 0.5304 \\
\hline$F(T)$ & $7.68^{*}$ & $22.35^{*}$ & $3.82^{\mathrm{ns}}$ & $42.53^{*}$ & & \\
\hline$P$ value $(T)$ & 0.0114 & $<0.0005$ & 0.0638 & $<0.0005$ & - & \\
\hline
\end{tabular}

${ }^{1}$ Means followed by the same letter (lower case by column or uppercase by line) do not differ significantly according to the Tukey test at $5 \%$ probability. C.i = Chrysodeixis includes; S.e = Spodoptera eridania; Def = Percentage of defoliation.

observed that PUI used in soybean did not result in higher grain yields and that this practice requires large amounts of pesticides, which may damage crop sustainability. Therefore, the use of IPM remains the best alternative for pest management in soybean cultivation. These results corroborate those of Bueno et al. (2011) in which the control strategies adopted in the present experiment did not influence soybean crop productivity.

\section{Materials and Methods}

\section{Plant materials and experimental site}

Seeds of the BMX Desafio - conventional and TEC Power IPRO - transgenic (Intacta) cultivars were sown under field conditions on 20 Nov. 2016.

The experiment was developed in Cristalina, Goiás, Brazil, at the geographical coordinates: Latitude: 16- 46 '07 "S and Longitude: 470 36' 49" W. According to the Köppen classification, the climate of the region is type $\mathrm{Cwb}$, which is defined as a tropical warm and temperate climate with average annual precipitation of $1422 \mathrm{~mm}$, rainy season during the summer and a dry season in the winter. The average temperature in the region during the experiment ranged between 20.4 and $21.3^{\circ} \mathrm{C}$.

\section{Field plots and trails}

The experimental design was in randomized blocks in a factorial scheme with four replications. The first factor was 2 cultivars (BMX Desafio - conventional and TEC Power IPRO transgenic - Cry $1 \mathrm{AC}$ ) and the second factor consisted of the strategies: BC, IPM, PUI and C (without pest control). The plots consisted of six $4.0 \mathrm{~m}$ rows, with $0.5 \mathrm{~m}$ spacing between the rows with a density of 20 plants/linear meter. The four central rows were considered the usable area.

In CB, nucleopolyhedrovirus (VPN-HzSNPV) was used. For the IPM, insecticides from the IGRs group were used, which are considered selective for natural enemies. For the PUI, insecticides from the pyrethroid group were used, which are normally preferred by soybean farmers in Brazil. They are usually cheaper and mixed with herbicides and fungicides and sprayed in a single operation (Bueno et al., 2011).

The applications of herbicide and fungicide were made when necessary. All products were sprayed with a $\mathrm{CO}_{2}$ pressurized backpack sprayer $\left(\right.$ Herbicat $^{\circledR}$ ) set for a spray volume of 150 L/ha using a Micron 1100B2 application tip. The cultural treatments were carried out according to Sediyama, 2009, except the insecticide application.

\section{Pest sampling}

The caterpillars were sampled during the vegetative and reproductive stages (Fehr and Caviness, 1977) using the sampling cloth methodology (Hoffmann-Campo et al., 2012). Sampling started at 30, 45, 60 and 75 DAPE counting the number of caterpillars in one linear meter per plot. The percentage of defoliation was estimated visually $(0-100 \%)$, attributing a PCLA representative of all plots (Pinheiro et al., 2005; Lourenção et al., 2010). When the plants reached physiological maturity, $4 \mathrm{~m}$ of the two central rows were harvested to determine grain productivity. The weight and moisture content of each sample were corrected to $13 \%$ seed moisture to obtain the productivity.

\section{Statistical analysis}

The data was submitted to ANOVA using the Shapiro-Wilk test to evaluate the normality of the residues. The averages were compared using the Tukey test at $5 \%$ probability. All analyses were performed using R software version 3.2.2 ( $R$ Core Team, 2017).

\section{Conclusion}

The transgenic TEC Power IPRO (Cry 1 Ac) cultivar presents efficiency in the control of $C$. includens and low efficiency for S. eridania. Harmonious practices such as IPM are the best 
alternative in soybean crop systems to minimize $C$. includens and S. eridania infestations. The control strategies adopted did not influence soybean crop productivity.

\section{Acknowledgments}

This study was partially supported by the 'Conselho Nacional de Desenvolvimento Científico e Tecnológico (CNPq)' Process 488225/2013-2 and the productivity research grant grant $311280 / 2015-3$ to F. G. Jesus. We also thank the "Instituto Federal Goiano - Campus Urutai" and Dr. Phillip John Villani (The University of Melbourne, Australia) who revised and corrected the English language used in this manuscript.

\section{References}

Bernardi O, Sorgatto RJ, Barbosa AD, Domingues FA, Dourado PM, Carvalho RA, Martinelli S, Head GP, Omoto C (2014) Low susceptibility of Spodoptera cosmioides, Spodoptera eridania and Spodoptera frugiperda (Lepidoptera: Noctuidae) to genetically modified soybean expressing Cry1Ac protein. Crop Prot. 58: 33-40.

Bobrowski VL, Fiuza LM, Pasquali G, Bodanese-Zanettini MH (2003) Genes de Bacillus thuringiensis: uma estratégia para conferir resistência a insetos em plantas. Cienc Rural. 34: 843-850.

Boiça Júnior AL, Bottega DB, Souza BHS, Rodrigues NEL, Michelim V (2015) Determinação dos tipos de resistência a Spodoptera cosmioides (W/ker) (Lepdoptera: Noctuidae) em genótipos de soja. Semina. 36: 607-618.

Bueno AF, Batistela MJ, Bueno RCOF, França-Neto JB, Nishikawa MAN, Libério Filho A (2011) Effects of integrated pest management, biological control and prophylactic use of insecticides on the management and sustainability of soybean. Crop Protec. 30: 937-945.

Bueno AF, Corrêa-Ferreira BS, Bueno RCOF (2010) Controle de pragas apenas com o MIP. A Granja. 733: 76-78.

Carmo EL, Bueno AF, Bueno RCOF, Vieira SS, Goulart MMP, Carneiro TR (2010) Seletividade de produtos fitossanitários utilizados na cultura da soja para pupas de Trichogramma pretiosum Riley 1879 (Hymenoptera: Trichogrammatidae). Arq Inst Biol. 77: 283-290.

Chocorosqui VR, Panizzi AR (2004) Impact of cultivation systems on Dichelops melacanthus (Dallas) (Heteroptera: Pentatomidae) populations and damage and its chemical control on wheat. Neotrop Entomol. 33: 487-492.

Faria CA, Wackers FL, Pritchard J, Barrett DA, Turlings TCJ (2007) High susceptibility of $B t$ maize to aphids enhances the performance of parasitoids of lepidopteran pests. PLoS One. 1-11.

Fehr WR, Caviness CE (1977) Stages of soybean development. Ames: lowa State University, 12p. (Special Report, 80).

Hoffmann-Campo CB, Corrêa-Ferreira BS, Moscardi F (2012) Soja: manejo integrado de insetos e outros artrópodes praga. Embrapa. 859 p.

Liu XX, Sun CG, Zhang QW (2005) Effects of transgenic Cry1A+CpTI cotton and Cry1Ac toxin on the parasitoid, Campoletis chlorideae (Hymenoptera: Ichneumonidae). Insect Sci. 12: 101-107.

Lourenção AL, Reco PC, Braga NR, Valle GE, Pinheiro JB (2010) Produtividade de genótipos de soja sob a infestação de lagarta-desoja e de percevejos. Neotrop Entomol. 39: 275-281.

Marques LH, Castro BA, Rossetto J, Silva OABN, Moscardini VF, Zobiole LHS, Santos AC, Valverde-Garcia P, Babcock JM, Rule DM,
Fernandes AO (2016) Efficacy of soybean's event das-81419-2 expressing Cry1F and Cry1Ac to manage key tropical lepidopteran pests under field conditions in Brazil. J Econ Entomol. 109: 19221928.

Martins GL, Tomquelski GV (2015) Eficiência de inseticidas sobre Chrysodeixis includens (Lepidoptera: Noctuidae) na cultura da soja. Rev Agr Neotrop. 4: 25-31.

Miranda MAC, Braga NR, Lourenção AL, Miranda FTS, Unêda SH, Ito MF (2003) Descrição, produtividade e estabilidade da cultivar de soja IAC-24, resistente a insetos. Bragantia. 62: 29-37.

Miranda R, Zamudio FZ, Bravo A (2001) Processing of Cry1Ab deltaendotoxin from Bacillus thuringiensis by Manduca sexta and Spodoptera frugiperda midgut proteases: role in protoxin activation and toxin inactivation. Insect Biochem Molec. 31: 11551163.

Naranjo SE (2005) Long-term assessment of the effects of transgenic $\mathrm{B} t$ cotton on the abundance of nontarget arthropod natural enemies. Environ Entomol. 34: 1193-1210.

Pinheiro JB, Vello NA, Rossetto CJ, Zucchi MI (2005) Potential of soybean genotypes as insect resistance sources. Crop Breed Appl Biotech. 5: 293-300.

R Core Team (2017) R: the R project for statistical computing. Vienna: R Foundation for Statistical Computing. Version 3.3.3.

Rahman K, Abdullah MAF, Ambati S, Taylor MD, Adang MJ (2012) Differential protection of Cry1Fa toxin against Spodoptera frugiperda larval gut proteases by cadherin orthologs correlates with increased synergism. Appl Environ Microbiology. 78: $354-$ 362.

Santos KB, Neves PJ, Meneguim AM, Santos RB, Santos WJ, Villas Boas G, Dumas V, Martins E, Praça LB, Queiroz P, Berry C, Monnerat R (2009) Selection and characterization of the Bacillus thuringiensis strains toxic to Spodoptera eridania (Cramer), Spodoptera cosmiodes (Walker) and Spodoptera frugiperda (Smith) (Lepidoptera: Noctuidae). Biol Control. 50: 157-163.

Sediyama T (2009) Tecnologia de produção e uso da soja. Londrina, Mecenas, 314p.

Seifi A, Visser RGF, Yuling BAI (2013) How to effectively deploy plant resistances to pests and pathogens in crop breeding. Euphytica.190: 321-334.

Smith, CM (2005) Plant resistance to arthropods: molecular and conventional approaches. Berlin, Springer. $423 \mathrm{p}$.

Souza PV, Machado BR, Freitas MM, Correa F, Almeida ACS, Jesus FG (2014b) Chrysodeixis includens (Lepdoptera: Noctuidae) soybean treated with resistance inducers. Afrc J Biotechnol.13: 4562-4567.

Souza PV, Machado BR, Silva DC, Menezes IPP, Araujo MS, Jesus FG (2014a) Efect of resistance and trichome inducers on attraction of Euchistus heros (Hemiptera: Pentatomidae) to soybeans. Afr J Agric Res. 9: 889-894.

Souza PV, Machado BR, Zanuncio JC, Araújo MS, Alves GC, Jesus FG (2016) Cultivation of resistant soybean varieties and application of silicon ( $\mathrm{Si}$ ) on biology of Euschistus heros (Hemiptera: Pentatomidae). Aust J Crop Sci. 10: 1404-1409.

Temple JH, Davis JA, Micinski S, Hardke JT, Price P, Leonard BR (2013) Species composition and seasonal abundance of stink bugs (Hemiptera: Pentatomidae) in Louisiana soybean. Environ Entomol. 42: 648-657.

Whitehouse MEA, Wilson LI, Constable GA (2007) Target and nontarget effects on the invertebrate community of Vip cotton, a new insecticidal transgenic. Aust J Agr Res. 58: 273-285.

Zalucki MP, Adamson D, Furlong MJ (2009) The future of IPM: whither or wither. Aust J Entomol. 48: 85-96. 